\title{
Field Based Quality Assessment of Cement
}

\author{
Er. Binod Aryal
}

Principal, Madan Bhandari Memorial Academy Nepal and Pokhara University, Urlabari 3, Morang, Nepal

DOI: $10.36348 /$ SJCE.2019.v03i05.005

| Received: 05.09.2019| Accepted: 25.09.2019| Published: 30.09.2019

*Corresponding author: Er. Binod Aryal

\section{Abstract}

Cement most conform the minimum standard for use. The study is focused to assess minimum quality of cement maintained at field practice at Lokanthali Area. The quality of cement in use at site was examined by manual field test and lab test was conducted for the confirmation of physical properties of most preferred cement brand as per Indian Standard Specifications. Also, secondary data were used to collect the relevant data for the analysis of the results. Hetauda cement being the highest consumer choice brand was tested in the lab. The 28 day compressive strength was found to be $47.48 \mathrm{Mpa}$ and $49.56 \mathrm{Mpa}$ for old and fresh cement respectively while other physical properties were confirmed as per Indian Standard Specifications. The results of 28 day compressive strength test shows that cement have less than 53 grades and greater than 43 grades. Since, 43 grade is enough for the general construction of structural element below M25 concrete grade, Hetauda cement can be considered as quality brand cement for such uses. It is recommended that manufacturer of Hetauda cement should increase its production capacity to meet the demand of the consumer.

Keywords: Visual inspection, Compressive strength, fresh and old cement.

Copyright @ 2019: This is an open-access article distributed under the terms of the Creative Commons Attribution license which permits unrestricted
use, distribution, and reproduction in any medium for non-commercial use (NonCommercial, or CC-BY-NC) provided the original author and source
are credited.

\section{INTRODUCTION}

In Nepal, Maoists revolution came to end in 2006 and after this period, several cement industries were significantly established with the growing infrastructure development works. Availability of multiple cement brands in the market made the brand selection a difficult process for the consumer. With this, marketing activities such as advertisement and brand promotion tools were significantly increased to attract the consumers and increase their desire for the specific brand. In the other hand, cement being the major symbol of strength, consumers seek the optimum quality of cement brand to use for the construction works. After unfreeze of development, Nepal is going through rapid infrastructure development activities lots of development activities are going on and the demand of cement is growing day by day for buildings, bridge, and road or hydropower project. Nepalese cement industries are continuously thriving to meet the demand of cement [1]. The Number of brands in cement industry is growing and with increase in number of brands, it is essential to understand how the consumers are attracted to the respective cement brands [2]. To succeed a Manufacturing or organization the product should be liked by the people. Till in Nepal company conform OPC 33 Grade only though 53 grade cement is cost effective in terms of quality, content and rate assessment[3] it was further argued that grading of Ordinary Portland Cement should be done. Even it was asked by Mishra and Chaudhary [4] that Inspection of cement in terms of quality should be done so that cement manufacturers could be compelled to maintain their quality. Hethauda Cement is found to be consumer's first choice among consumer of Bhaktpur District [5].

\section{Objectives of the Study}

The overall objective of this study is to conform the quality of cement to highest consumer choice.

\section{LITERATURE REVIEW Cement}

Cement is a fine powder, which when mixed with water undergoes chemical change and thereafter allowed to set and harden is capable of uniting fragments or masses of solid matter together to produce a mechanically strong material. Cement can be used as binding material with water, for bonding solid particles of different sizes like bricks, stones or aggregate to form a monolith. Cements used in construction of buildings and civil engineering works contain compounds of lime, silica and alumina as their principal constituents and can be called as complex compounds. 
Cement is a very essential commodity used in the construction of buildings and other structures. Cement is a binder, a substance which sets and hardens independently, and can bind other materials together. It is also the second most consumed material on the planet [6].

\section{Types of Cement}

There are some varieties in cement that always find good demand in the market. Among the different varieties of cement, Nepal produces Ordinary Portland Cement (OPC), Portland Pozzolana Cement (PPC), and Portland Slag Cement (PSC).

\section{Ordinary Portland cement (OPC)}

Also, referred to as grey cement or OPC, it is of much use in ordinary concrete construction. In the production of this type of cement, Iron $\left(\mathrm{Fe}_{2} \mathrm{O}_{3}\right)$, Magnesium $(\mathrm{MgO})$, Silica $\left(\mathrm{SiO}_{2}\right)$, Alumina $\left(\mathrm{AL}_{2} \mathrm{O}_{3}\right)$, and Sulphur trioxide $\left(\mathrm{SO}_{3}\right)$ components are used. OPC comes in 3 different grades-Ordinary Portland cement 33, 43, 53 grades (OPC), 53-S (Sleeper Cement). 33, 43 and 53 grade in OPC indicates the compressive strength of cement after 28 days when tested as per IS: 40311988, eg, 33 Grade means that 28 days of compressive strength is not less than $33 \mathrm{~N} / \mathrm{mm} 2$ (MPa). Similarly, for 43 grades and 53 grades the 28 day compressive strength should not be less than 43 and $53 \mathrm{MPa}$ respectively [7].

\section{Portland Pozzolana Cement (PPC)}

As it prevents cracks, it is useful in the casting work of huge volumes of concrete. The rate of hydration heat is lower in this cement type. Fly ash, coal waste or burnt clay is used in the production of this category of cement. It can be available at low cost in comparison to OPC. PPC produces less heat of hydration and offers greater resistance to attack of aggressive environment gives long-term strength and enhances the durability of structures. PPC is manufactured by inter grinding OPC clinker with 15$35 \%$ of pozzolanic material. Pozzolanas are essentially siliceous or aluminous material, which in itself possesses no cementitious properties, which will be in finely divided form and in the presence of moisture react with calcium hydroxide, liberated in the hydration process, at ordinary temperature, to form compounds possessing cementitious properties. The pozzolanic materials generally used are fly ash or calcined clay. PPC is used in heavy load infrastructure and constructions such as marine structures, hydraulic structures, mass concreting works, plastering, masonry mortars, and all applications of ordinary Portland cement [6].

\section{Portland Slag Cement (PSC)}

PSC consists of 45 per cent clinker, 50 per cent blast furnace slag and 5 per cent gypsum. It has a heat of hydration even lower than PPC and is generally used in the construction of dams and similar massive constructions. PSC is obtained by mixing blast furnace slag, cement clinker and gypsum and grinding them together to get intimately mixed cement. The quantity of slag varies from 30-70\%. The gain of strength of PSC is somewhat slower than OPC. PPC and PSC can be used in all situations where OPC is used, but are preferred in mass construction where lower heat of hydration is advantageous or in marine situations and structures near seacoast or in general for any structure where extra durability is desired. For example, Marine structure, structures near the sea, sewage disposal treatment works, water treatment plants and other similar types of structures [8].

\section{Cement Manufacturing Technology}

The manufacturing process of cement consists of the mixing, drying and grinding of limestone, clay and silica into a composite mass. The mixture is then heated and burnt in a pre-heater and kiln to be cooled in an air cooling system to form clinker, which is the semi-finished form. This clinker is cooled by air and subsequently ground with gypsum to form cement.

Portland cements are made by grinding a mixture of limestone, clay and other corrective materials, viz. Laterite, Bauxite, etc. Essential constituents mainly are Lime, Silica, Alumina and Iron Oxide. The process of manufacturing consists of grinding of raw materials into fine powder, mixing them and burning in a kiln at about $1400{ }^{\circ} \mathrm{C}$. The resultant product is called Clinker. Clinker is cooled, ground to fine powder with gypsum. The end product is cement.

There are three types of processes to form cement - the wet, semi-dry and dry processes. In the wet/semi-dry process, raw material is produced by mixing limestone and water (called slurry) and blending it with soft clay. In the dry process technology, crushed limestone and raw materials are ground and mixed together without the addition of water [9].

\section{Wet Process}

When chalk is used, it is finely broken up and dispersed in water in a wash mill. The clay is also broken up and mixed with water, usually in a similar wash mill. The two mixtures are now pumped so as to mix in predetermined proportions and pass through a series of screens. The resulting - cement slurry - flows into storage tanks. When limestone is used, it has to be blasted, then crushed, usually in two progressively smaller crushers (initial and secondary crushers), and then fed into a ball mill with the clay dispersed in water. The resultant slurry is pumped into storage tanks. From here onwards, the process is the same regardless of the original nature of the raw materials. The slurry is a liquid of creamy consistency, with water content of between 35 and $50 \%$, and only a small fraction of material - about $2 \%$ - larger than a $90 \mu \mathrm{m}$ (sieve No. 170). The slurry mix mechanically in the storage tanks, 
and the sedimentation of the suspended solids being prevented by bubbling by compressed air pumped from bottom of the tanks. The slurry is analyzed chemically to check the achievement of the required chemical composition, and if necessary changing the mix constituents to attain the required chemical composition. Finally, the slurry with the desired lime content passes into the rotary kiln. This is a large, refractory-lined steel cylinder, up to $8 \mathrm{~m}$ in diameter, sometimes as long as $230 \mathrm{~m}$, which is slightly inclined to the horizontal. The slurry is fed in at the upper end while pulverized coal (oil or natural gas also might be used as a fuel) is blown in by an air blast at the lower end of the kiln, where the temperature reaches about 1450 deg. C. The slurry, in its movement down the kiln, encounters a progressively higher temperature. At first, the water is driven off and $\mathrm{CO} 2$ is liberated; further on, the dry material undergoes a series of chemical reactions until finally, in the hottest part of the kiln, some 20 to $30 \%$ of the material becomes liquid, and lime, silica and alumina recombine. The mass then fuses into balls, 3 to $25 \mathrm{~mm}$ in diameter, known as clinker which finally drops into coolers $[9,10]$.

\section{Dry Process}

The raw materials are crushed and fed in the correct proportions into a grinding mill, where they are dried and reduced in size to a fine powder. The dry powder, called raw meal, is then pumped to a blending silo, and final adjustment is now made in the proportions of the materials required for the manufacture of cement. To obtain a uniform mixture, the raw meal is blended in the silo, usually by means of compressed air. The blended meal is sieved and fed into a rotating dish called a granulator, water weighing about $12 \%$ of the meal being added at the same time. In this manner, hard pellets about $15 \mathrm{~mm}$ in diameter are formed. The pellets are baked hard in a pre-heating grate by means of hot gases from the kiln. The pellets then enter the kiln, and subsequence operations are the same as in the wet process of manufacture $[7,11,12]$.

\section{METHODOLOGY}

\section{Method of Data Collection}

Digonosti Research Approach is Adopted and for visual inspection ex post facto research design is adopted

\section{Primary Data}

The primary data was collected from key informant interview, observation and lab tests.

\section{Field Observation}

During the site visit, observation of cement was done with the manual field test with different test paramters that are done to find the quality of cement. Out of 89 sample size of consumer, only 30 samples were in the phase of structural works due to which cement were available in the site. Thus, 30 samples were collected and tested in the field. The test parameters were as show in table 3.1 below:

Table-Error! No text of specified style in document..1: Field Test Parameter, Procedure and Standard Requirement of Cement

\begin{tabular}{|l|l|l|}
\hline S. No & \multicolumn{1}{|c|}{ Test Parameter } & \multicolumn{1}{c|}{ Procedure and Standard Requirement } \\
\hline 1 & Cement Colour & Colour should be uniform with typical grey colour with a light greenish shade \\
\hline 2 & Water Sinking Test & $\begin{array}{l}\text { If a small quantity of cement is thrown into the water, it should float some time } \\
\text { before finally sinking }\end{array}$ \\
\hline 3 & Presence of Lumps & $\begin{array}{l}\text { Cement should be free from hard lumps which means there is no absorption of } \\
\text { moisture from the atmosphere }\end{array}$ \\
\hline 4 & Smoothness Test & $\begin{array}{l}\text { When cement is touched, or rubbed in between fingers, it should give a smooth } \\
\text { feeling }\end{array}$ \\
\hline 5 & $\begin{array}{l}\text { Temperature Inside } \\
\text { Cement Bag }\end{array}$ & $\begin{array}{l}\text { If the hand is plunged into a bag of cement, it should be cool inside the cement } \\
\text { bag }\end{array}$ \\
\hline 6 & $\begin{array}{l}\text { Glass Plate Test (Setting } \\
\text { Test) }\end{array}$ & $\begin{array}{l}\text { A thick paste of cement with water is made on a piece of glass plate and is kept } \\
\text { under water for 24 hours. It should set without any cracks }\end{array}$ \\
\hline
\end{tabular}

\section{Lab Tests}

The cement brand with highest preference by the consumers was tested in the lab of G.S Engineers \& Soil Materials Pvt. Ltd. Two cement samples were collected in the lab; cement from the consumers' construction site and the fresh cement from the supplier. In the lab, physical parameters of the cement were tested to confirm the quality of cement in the presence of the technician staff of the Lab. Following tests were conducted in the lab;

\section{Fineness Test}

It is the test method of determining the fineness of the cement. It affects the rate of hydration which is responsible for the rate of strenght gain. The smaller the particle size, the greater the surface area to volume ratio, which means more area availabe for water-cement reaction per unit volume. It was carried out by dry sieving as per IS: 4031 (Part 1) - 1996.The principle of this test was to determine the proportion of cement whose grain size is larger than specified mesh size. The apparatus used were $90 \mu \mathrm{m}$ IS Sieve, Balance 
capable of weighing $10 \mathrm{~g}$ to the nearest $10 \mathrm{mg}$, A nylon or pure bristle brush, preferably with 25 to $40 \mathrm{~mm}$, bristle, for cleaning sieve.

\section{Consistency}

Consistency of a cement paste refers to its ability to flow. The basic aim of this test is to find out the water content required to produce a cement paste of standard consistency as specified by the IS: 4031 (Part $4)-1988$. The principle is that standard consistency of cement is that consistency at which the Vicat plunger penetrates to a point $5-7 \mathrm{~mm}$ fromthe bottom of Vicat mould. Vicat apparatus conforming to IS: 5513 - 1976, Balance, whose permissible variation at a load of $1000 \mathrm{~g}$ should be $+1.0 \mathrm{~g}$, Gauging trowel conforming to IS: $10086-1982$.

\section{Soundness Test}

Soundess of cement refers to the ability of a hardened cement paste to retain its volume after setting. Soundness of cement was determined by Le-Chatelier method as per IS: 4031 (Part 3) - 1988. To find the soundness of the cement, normal consistency was first carried out to find the standard consistency of the cement. Then the paste is prepared by adding 0.78 times the water required to give a paste of standard consistency. The prepared paste is then filled in Lechatelier mould and was covered with piece of lightly oiled glass sheet. The whole assembly was then submerged in water at a temperature of $27 \pm 2^{\circ} \mathrm{C}$ and kept for 24 hours. After 24 hours, whole assembly was removed from water bath and the distance separating the indicators to the nearest $0.5 \mathrm{~mm}$ (L1) was measured. Again, the whole assembly was submerged in water bath and brought to the boiling temperature in 25 to 30 minutes. It was kept in a boiling temperature for a period of 3 hours. After completion of 3 hours, water bath was cooled down to the room temperature and whole assembly was removed from water bath. Then, the distance between two indicator points to the nearest $0.5 \mathrm{~mm}$ (L2) was measured. Finally, the mean of two values to the nearest $0.5 \mathrm{~mm}$ was calculated as the soundness of the cement.

\section{Initial and Final Setting Time Test}

Initial and final setting time was conducted as per IS: 4031 (Part 5) - 1988 using Vicat apparatus conforming to IS: 5513 - 1976 and Balance, whose permissible variation at a load of $1000 \mathrm{~g}$ should be $+1.0 \mathrm{~g}$, Gauging trowel conforming to IS: $10086-1982$. About 400g cement and 0.85 times standard consistency water quantity were mixed on impervious surface. The mould was filled immediately with the prepared cement paste and the surface of cement was smoothed in the mould. The needle of the appartus was then lowered to touch the surface of the cement paste and allowed to sink in the surface. During the first insertion of needle, it pierces the whole test block and same process was repeated every 15 minutes until the needle failed to pierce $5 \pm 0.5 \mathrm{~mm}$ when measured from bottom of the mould. The time of adding water to the time failing the needle to pierce the test block by $5 \pm 0.5 \mathrm{~mm}$ was recorded as the initial setting time of the cement. After the completion of that test, needle was changed with another needle and the same process was followed and the time the needle makes the mark to the time that its annular part fails to do so was recorded. The final setting time was recorded as the time from the adding of the water to the time that its annular parts fail to make the mark.

\section{Compressive Strength Test}

Compressive strength test was carried out by mixing cement and mortar of standard proportion as per IS: 4031(Part 6-1988) using vibration machine in a mortar cubes. The cubes were tested under a compression testing machine applying the load in its cross-sectional area. The strength of cement varies with time. Thus, 7 days and 28 day strength were tested for both cement sample taken from the consumer and the supplier.

\section{Secondary Data}

The Secondary data were collected from the published/ unpublished documents, literatures, previous research of consumer behaviours, brand and advertisements. Standard codes were collected from Indian Standard codes for the calculation of physical parameter of cement and to confirm their quality.

\section{DATA ANALYSIS}

The collected data were analyzed with qualitative as well as quantitative technique. The data collected were entered, classified, tabulated and interpreted accordingly using relative importance factor, mean score and standard deviation. MS- Excel and other computer aided suitable tools are used for the processing, analysis and the presentation of the data collected, and they were logically interpreted with appropriate tables/ charts to find the objectives of the study.

\section{Quality of Cement}

Sample of different cement brands selected by the consumers were observed in the site to test the quality of cement. Out of 89 sample population, field test of 30 samples were done due to unavailability of cement in the remaining sample population. Table 4.9. shows the field test of the cement brands selected by the consumers. 
Table-Error! No text of specified style in document..2: Field observation of Cement

\begin{tabular}{|c|c|c|c|c|c|c|c|c|}
\hline S.N & $\begin{array}{l}\text { Test } \\
\text { Parameter }\end{array}$ & Results & Hetauda & Udayapur & Shivam & Maruti & Argakhanchi & $\begin{array}{l}\text { Standard } \\
\text { Requirement }\end{array}$ \\
\hline 1 & $\begin{array}{l}\text { Cement } \\
\text { Colour }\end{array}$ & Grey & 15 & 7 & 6 & 1 & 1 & Grey \\
\hline \multirow[t]{2}{*}{2} & \multirow[t]{2}{*}{$\begin{array}{l}\text { Water } \\
\text { Sinking Test }\end{array}$} & $\begin{array}{l}\text { Float for some } \\
\text { time before } \\
\text { sinking }\end{array}$ & 13 & 6 & 6 & 1 & 1 & \multirow[t]{2}{*}{$\begin{array}{l}\text { Float for some } \\
\text { time before } \\
\text { sinking }\end{array}$} \\
\hline & & Immediately sunk & 2 & 1 & 0 & 0 & 0 & \\
\hline \multirow[t]{2}{*}{3} & \multirow[t]{2}{*}{$\begin{array}{l}\text { Presence of } \\
\text { Lumps }\end{array}$} & $\begin{array}{l}\text { Free from hard } \\
\text { lumps }\end{array}$ & 11 & 7 & 4 & 1 & 1 & \multirow[t]{2}{*}{$\begin{array}{l}\text { Free from hard } \\
\text { lumps }\end{array}$} \\
\hline & & Small lumps & 4 & 0 & 2 & 0 & 0 & \\
\hline 4 & $\begin{array}{l}\text { Smoothness } \\
\text { Test }\end{array}$ & $\begin{array}{l}\text { Smooth feeling } \\
\text { when rubbed }\end{array}$ & 15 & 7 & 6 & 1 & 1 & $\begin{array}{l}\text { Shall be } \\
\text { smooth when } \\
\text { rubbed }\end{array}$ \\
\hline \multirow[t]{2}{*}{5} & \multirow{2}{*}{$\begin{array}{l}\text { Temperature } \\
\text { Inside } \\
\text { Cement Bag }\end{array}$} & Cool & 14 & 6 & 4 & 1 & 1 & \multirow[t]{2}{*}{ Cool } \\
\hline & & Warm & 1 & 1 & 2 & 0 & 0 & \\
\hline 6 & $\begin{array}{l}\text { Glass Plate } \\
\text { Test(Setting } \\
\text { Test) }\end{array}$ & $\begin{array}{l}\text { Set without cracks } \\
\text { after } 24 \mathrm{hrs}\end{array}$ & 15 & 7 & 6 & 1 & 1 & $\begin{array}{l}\text { Shall set } \\
\text { without any } \\
\text { cracks after } 24 \\
\text { hrs. }\end{array}$ \\
\hline
\end{tabular}

Field test result shows that almost all cement samples have met the standard requirements while 3 samples failed the Water Sinking Test out of 30 samples. Similarly, 6 samples were found with small lumps in the cement and 4 samples were found to be warm when the hand is plunged into a bag of cement

Since, Hetauda cement was found to be used by $50 \%$ of totals sample population. The physical parameters of the Hetauda cement were tested in the lab to confirm its quality.

\section{Fineness of Cement}

According to IS code, IS-8112, IS-1478, Part1 , the percentage of mass retained in 90 microns IS sieve should be less thand $10 \%$. Fineness of cement is linked with the rate of hydration for the rapid development of strength. The fineness of Hetauda cement was found to be $96.20 \%$ which fulfilled the stanndard requirement as per IS code.

\section{Normal Consistency of Cement}

Consistency of cement test does not affect the physical property of cement but it is the governing medium for the full hydration of cement paste. Normal consistency of cement is defined as the standard consistency which will permit the Vicat plunger as per IS5513(1976) to penetrate to a point $5 \mathrm{~mm}$ to $7 \mathrm{~mm}$ from the bottom of Vicat mould when cement paste is tested as per IS 4031 part-4. During the test, the normal consistency of Hetauda cement was found to be $28 \%$ while it should be between the ranges of $26 \%$ to $33 \%$ for the proper hydration of cement.

\section{Initial and Final Setting Time}

According to IS 8112(1989) and IS 1478(1978), the minimum initial setting time for cement should be 30 minutes and maximum final setting time should not exceed 600 minutes.

From the test, it was found that initial setting time of Hetauda cement was 185 minutes while final setting time was 374 minutes which is the satisfactory result as it meets the requirement of IS code.

\section{Soundess of Cement}

According to IS 8112(1989) and IS 1478(1978), the maximum autoclave expansion should not be greater than $0.8 \%$ which means that the change in initial and final length of the speciment should not be greater than $0.8 \%$ by its initial length.

Soundess test of Hetauda cement shows that $0.5 \%$ expansion by its initial length which means that its expansion is less than the allowable expansion as per IS code.

\section{Compressive strength test of Cement}

For the test of compressive strengtht of cement, cement is mixed with sand and aggregate in the ratio 1:1.5:3(M20 grade) with required water cement ratio. The concrete is then poured in the $15 \mathrm{~cm} \times 15 \mathrm{~cm} \times 15 \mathrm{~cm}$ standard mould as per IS code and compacted using the vibrator.

According to the test result, 7 days and 28 days of compressive strength of Hetauda cement was found to be $35.63 \mathrm{Mpa}$ and $46.48 \mathrm{Mpa}$ respectively. Thus, the cement is found to have greater grade with respect to the standard grade of $43 \mathrm{Mpa}$ which is enough for the general structural elements. Since, the cement sample was taken from the consumer construction site which was already 24 days of purchase from the supplier, the test result was affected due to its aging. Thus, fresh cement was again taken from the 
supplier immediately after the delivery from the factory.

Table-Error! No text of specified style in document..3: Physical properties of Hetauda cement

\begin{tabular}{|c|c|c|c|c|}
\hline $\mathbf{S . N}$ & Physical Properties & $\begin{array}{l}\text { Cement } \\
\text { sample taken } \\
\text { from the site }\end{array}$ & $\begin{array}{l}\text { Cement sample } \\
\text { taken from the } \\
\text { supplier }\end{array}$ & $\begin{array}{l}\text { Requirement as per IS } \\
\text { specifications }\end{array}$ \\
\hline 1 & Normal Consistency & $28 \%$ & $28 \%$ & $26 \%$ to $33 \%$ \\
\hline 2 & Fineness Test & $96.20 \%$ & $96.90 \%$ & $\begin{array}{l}\text { Not Specified( }>90 \% \\
\text { considered fresh) }\end{array}$ \\
\hline 3 & Specific Gravity & 3.12 & 3.1 & $\begin{array}{l}\text { Not more than } \\
3.19 \text { (Considered moist) }\end{array}$ \\
\hline 4 & Soundness Test & $7 \mathrm{~mm}$ & $5 \mathrm{~mm}$ & Not more than $10 \mathrm{~mm}$ \\
\hline 5 & Initial Setting Time & 185 mins & 130 mins & Minimum 60 minutes \\
\hline 6 & Final Settinng Time & 374 mins. & 380 mins. & Maximum 600 minutes \\
\hline \multirow[t]{2}{*}{7} & \multirow[t]{2}{*}{7 days Compressive Strength } & $35.63 \mathrm{Mpa}$ & $39.04 \mathrm{Mpa}$ & \multirow[t]{2}{*}{$33 \mathrm{Mpa}$} \\
\hline & & \multicolumn{2}{|c|}{ Average $=37.33 \mathrm{Mpa}$} & \\
\hline \multirow[t]{2}{*}{8} & \multirow[t]{2}{*}{28 days Compressive Strength } & $46.48 \mathrm{Mpa}$ & 49.56Mpa & \multirow[t]{2}{*}{$43 \mathrm{Mpa}$} \\
\hline & & \multicolumn{2}{|c|}{ Average $=48.02 \mathrm{Mpa}$} & \\
\hline
\end{tabular}

\section{CONCLUSIONS}

With the objective of testing the physical parameters of the highest consumer choice cement, consistency, soundness, fineness, setting time and compressive strength of cement was tested in the lab. The soundness test of the Hetauda cement was found to be $7 \mathrm{~mm}$ expansion determined by Le-Chatelier method which was within the Indian standard specification of less than $10 \mathrm{~mm}$ expansion. Similarly, fineness was $96.2 \%$ which means the percentage residue retained on the 90 micron IS sieve was $3.8 \%$ only. The initial setting time and final setting time were 185 and 374 minutes respectively and were within the minimum range of 30 minutes for initial setting time and maximum of 600 minutes for final setting time.

For the compressive strength test, the result obtained was 37.33Mpa and 48.02Mpa for 7 day and 28 day compressive strength respectively. Since, Nepal Bureau of Standard and Metrology have no provision of grading above $33 \mathrm{Mpa}$ cement grade; none of the cement in the country has mentioned the grade in cement. Therefore, the grade of the Hetauda cement was found to be 43 which meet the required strength for the construction of residential buildings.

Hence, it can be concluded that Hetauda cement being the highest consumer choice is the good quality cement as it meets all the standard physical parameter as per Indian Standard Specifications.

\section{RECOMMENDATION}

Hetauda cement manufacturer should increase its production capacity to meet the demand of the consumer during any period of the year which couldpotentially leads to consumer to change into 'Committed Loyal Consumer'. Quality and brand image are the most imporant determinants to choose the cement brands for the construction of the building of consumer. Thus, the manufacturers should confirm the quality of their brand in the effective way which helps to create the brand image in the market.

\section{REFERANCES}

1. Mishra, A.K., Jha, A.(2019). Quality Assessment of Sarbottam Cement of Nepal. International Journal of Operations Management and Services, 9(1): 1-22. http:// www.ripublication.com

2. Jha, A., Mishra, A.K. (2019). Assessment of the Structure of Credit Policy and Sales Trend of Sarbottam Cement. J Adv Res Busi Law Tech Mgmt, 2(1): 14-20.

3. Mishra, A.K., Chaudhary, U. (2018). Cost Effectiveness Assessment of Different Nepalese Cement Brands for Selected Sites of Supermarket. J Adv Res Const Urban Arch, 3(3): 12-33.

4. Mishra, A.K., Chaudhary, U. (2018). Assessment of Cement Handling Behaviour For Selected Construction Sites of Bhatbhateni Supermarket. J Adv Res Const Urban Arch, 3(3): 1-11.

5. Mishra, A.K., \& Sharestha, B.(2002). Assessment of Consumer Influencing Factor in Decision Making for Selecting Cement Brands South Asian Research Journal of Business and Management

6. World Business Council for Sustainable Development. (2002). Annual Report. Accessed from $w w w$.wbcsd.org

7. Salah, B. (2017). Concrete Technology: Chapter 1.

8. Kannan, L. (2009). Study of Consumer Behaviour in Cement Decision making.

9. Mahasenan, N., Smith. S., Humphreys, K., \& Y. Kaya. (2003). The Cement Industry and Global Climate Change: Current and Potential Future Cement Industry.

10. Indian Bureau of Standards. (1976). Specification for Ordinary Portland cement.

11. Indian Bureau of Standards. (1978). Specification for Ordinary Portland cement.

12. Indian Bureau of Standards. (1989). Specification for Ordinary Portland cement. 